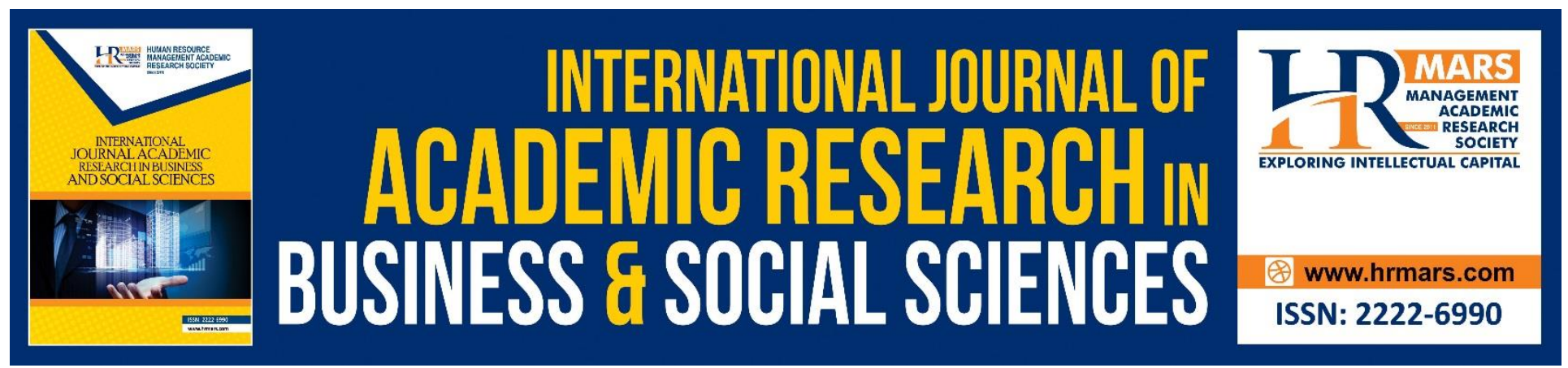

\title{
Effect of Cashless Payments on the Financial Performance of Supermarkets in Nairobi County, Kenya
}

Jumba, J., Wepukhulu, J.M.

To Link this Article: http://dx.doi.org/10.6007/IJARBSS/v9-i3/5803

DOI: $10.6007 /$ IJARBSS/v9-i3/5803

Received: 01 Feb 2019, Revised: 15 Feb 2019, Accepted: 08 March 2019

Published Online: 25 March 2019

In-Text Citation:(Jumba \& Wepukhulu, 2019)

To Cite this Article: Jumba, J., \& Wepukhulu, J. M. (2019). Effect of Cashless Payments on the Financial Performance of Supermarkets in Nairobi County,Kenya. International Journal of Academic Research Business and Social Sciences, 9(3), 1372-1397.

Copyright: (C) 2019 The Author(s)

Published by Human Resource Management Academic Research Society (www.hrmars.com)

This article is published under the Creative Commons Attribution (CC BY 4.0) license. Anyone may reproduce, distribute, translate and create derivative works of this article (for both commercial and non-commercial purposes), subject to full attribution to the original publication and authors. The full terms of this license may be seen

at: http://creativecommons.org/licences/by/4.0/legalcode

Vol. 9, No. 3, 2019, Pg. 1372- 1397

http://hrmars.com/index.php/pages/detail/IJARBSS

JOURNAL HOMEPAGE

Full Terms \& Conditions of access and use can be found at http://hrmars.com/index.php/pages/detail/publication-ethics 


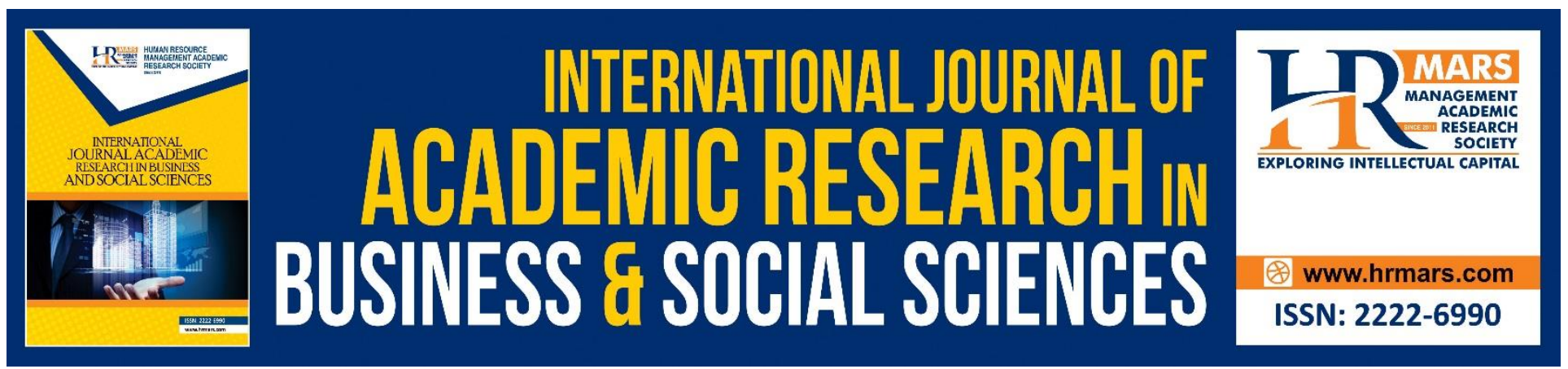

\title{
Effect of Cashless Payments on the Financial Performance of Supermarkets in Nairobi County, Kenya
}

\author{
Jumba, J. \\ Master Student, Jomo Kenyatta University of Agriculture and Technology, (JKUAT), Kenya
}

Dr. Wepukhulu, J. M.

Lecturer, Jomo Kenyatta University of Agriculture and Technology (JKUAT), Kenya

\begin{abstract}
Along with popularity of electronic commerce and online purchasing, cashless payment systems have been developed and expected to the main payment means of e-commerce globally. Kenya is still at the inception stage with $27 \%$ of the consumer payments being cashless. Despite the benefits associated with electronic money payments, Supermarkets in Nairobi County have generally been slow in adopting the use of cashless payments. Thus, this research intended to investigate the effects of cashless payments on financial performance of supermarkets in Nairobi County. Of specific focus was how financial accessibility, financial innovation, cash handling practices and transaction costs influence financial performance of supermarket in Nairobi County. This study examines the recent trends of effects of cashless payments on the financial performance of supermarkets in Nairobi County for the period January 2015 to December 2017. Taking a descriptive research design, the study accomplishes the objectives by focusing on the finance managers of the supermarkets in Nairobi County. The target population comprised of 147 supermarket branches in Nairobi County. Systematic random sampling was used to calculate a sample size of 66 respondents. Linear regression analysis was used to test the relationship between the independent and the dependent variables. The results of the analysis were presented in form of tables, graphs and charts. From the findings the study concluded that financial accessibility, financial innovations, cash handling practises and transactions costs significantly influences financial performance. From the conclusions the study recommended that there is need for supermarkets in Nairobi County to improve financial accessibility to the various payments platforms and accept the different payment innovations in the market. The study further recommended that supermarkets should reduce transaction costs of payment channels to increase adoption. This will have a positive impact on the financial performance of supermarkets in Nairobi County.
\end{abstract}


INTERNATIONAL JOURNAL OF ACADEMIC RESEARCH IN BUSINESS AND SOCIAL SCIENCES

Vol. 9, No. 3, March, 2019, E-ISSN: 222 2-6990 ㄷ 2019 HRMARS

Keywords: Adoption, Financial Accessibility, Financial Innovations Cashless Payments, Cash Handling Practices, Transaction Costs, Financial Performance.

\section{Background of the Study}

Information technology has impacted every feature of life, changing subsistence social orders into modernized social societies. The installment framework isn't let alone for this change. Son and Kim (2018) state that organizations can't disregard data innovation, since it assumes an imperative job in keeping up aggressive edge both locally and comprehensively, and that most organizations money streams are complicatedly connected to their appropriation of data innovation. In developed nations today and in developing countries, electronic payment are broadly acknowledged. Majorly, buyers can choose how they make and get installments, adjusting a scope of qualities, for example, comfort, security, speed as well as cost (Son \& Kim, 2018).

According to Solat (2017) payment systems have evolved into a near cashless society. This has been encouraged by the high development in ICT, Federal laws and presence of a financial industry both public and private offering monetary clearing services such as banks, credit card companies and automatic clearing houses. These forms of cashless payments include mainly credit cards, cheques, debit cards and electronic money transfers. Credit cards are the most frequently used electronic payment instrument in the United States (Balaji \& Balaji, 2017). The introduction of cashless payment systems was aimed at reducing cost of money management, expanding effectiveness of the payment framework and driving monetary consideration. Świecka (2015) opines that the expanded utilization of cashless payment framework has prompted forecast of a cashless society. In a cashless society, shoppers can make installments over the web, installment at unmanned candy machine, kept an eye on POS utilizing cell phone, savvy cards and other electronic installment frameworks.

Thomas and Angus (2013) find the combination of demographic and financial characteristics, detailed supply-side factors, and new technology adoption in a single analysis are unique where cashless payments are concerned. Further, transaction cost is found to have the greatest effect on the adoption of cashless payments as perceived by the consumer. Credit transfer is by far the most commonly used payment medium in Belgium. The use of cheques, as a cashless payment instrument, has been declining steadily as commercial banks gradually increased cheque fees. Buyers have turned out to be mindful of the benefits of cashless installments and as their acknowledgment of these installments builds, an ascent in the supply of products and enterprises that can be purchased through the cashless stage is normal (Upadhyay \& Jahanyan, 2016). It very well may be said about the future, that cashless installments will most likely be unable to substitute the customary physical wallet and may along these lines simply supplement existing installment arrangements (Solat, 2017). However, it is additionally a probability that a substitution will happen bit by bit and first following quite a long while be finished Shukla (2017). Regardless of what will occur, investigating what properties the clients find valuable in an electronic wallet, is a stage in transit towards a cashless society. 
Payment cards are more secure and convenient for the consumers. More than 1.2 billion credit cards are now in use around the world, accepted at more than 23 million locations (Solat, 2017). The payments cards are now even more convenient with the wireless computer network which has allowed the POS to go mobile. Payment can now be done at the customers point this has increased customer satisfaction especially in the hotel industry where the technology has already been embraced. Cashless payment tends to benefit businesses by extending customers base, boosting cash flow, reducing costs, enhancing customer service and improving competitive advantage. Cashless payment improves customer service by providing choices; it can offer a wide range of payment options which makes it convenient to perform transactions (Akhisar \& Tunay, 2015). The varieties in payment options also bring about competition with competitor trying to offer full range of payment options (Rafique, Rizwan, Batool \& Aslam, 2014).

Numerous African markets have been building the foundation for cashlessness for quite a while including moderate and comprehensively accessible money related items, a lively and aggressive vendor commercial center, a straightforward and beneficial business condition (Agwu and Carter, 2014). Likewise, Africa's administrations and Central Banks are looking to enhance money related incorporation and drive in-bound venture, new and energizing open doors are developing for both conventional banks and Financial Technology new companies. In the last decade, innovation in the financial services sector in Africa has seen the introduction of internet banking, multi-currency cards and mobile money transactions amongst other things. Africa is on a steady growth path with a more progressive approach in terms of financial services adopting technology (Agwu \& Carter, 2014). In South Africa approximately $30-35 \%$ of retail payments are electronic and $60-65 \%$ are cash payments (Thomas \&Angus, 2013). Kenya is ranked second in Africa among countries that have significantly adopted cashless payments system (Thomas \& Angus, 2013). They further note that $27 \%$ of Kenyans had fully adopted the cashless system for settling bills, buying goods and paying for various services with the number rising sharply due to reliable mobile phone cash transactions. Kenya's Trajectory reflects a substantial shift in share of consumer payment value from cash to M-Pesa between 2006 and 2011.

Past investigations on the cashless payments have acknowledged the role it plays on financial performance. Mugambi, et.al (2014) in their study on the effect of the credit cards on the performance of retail firms' portfolio acknowledges the fact that the credit cards have a positive effect on the financial performance of the commercial banks in Kenya. Kamar (2012) in the study on the effect of the electronic credit card usage on a firm agrees with Odhiambo (2012) that there is a positive effect between the number of the credit cards, the net income from the credit cards and the profitability. Muiru (2014) in his study the effects of financial innovation on financial performance of retailers found out that the firms that had adopted some forms of financial innovation like the credit cards, mobiles and agency banking and these had a great impact on the financial performance of the retailers. According to CBK annual reports (2018), the value of transactions effected through cards in the year to June 2017 increased by 6.4 percent and 79.1 percent from Kshs 673.31 billion to Kshs716.44 billion for acquirers and issuers, respectively. The growing usage of card signifies a growing shift from cash based payments to non-cash based payments (Kosse \& Welte, 2017). 
Thomas and Angus (2013) indicate that Kenya is second to South Africa as the most formalized African country in terms of formal retail penetration with retail penetration standing at around 30 per cent. The retail market is dominated by three major outlets; Tuskys, Uchumi and Naivas (Euromonitor report, 2018). Three of them (except Naivas) have already crossed into the neighbouring countries. Nakumatt is the largest retailer in Kenya in terms of sales. It has 37 stores, followed by Tuskys which has 37 outlets, Uchumi 18 outlets and then Naivas with 19 branches. Nakumatt is also present in Uganda, Tanzania and Rwanda, while Tuskys and Uchumi are also in Uganda. Use of the formal outlets increases customer choices, while creating employment.

\section{Statement of the Problem}

In the past, studies have addressed conceptual issues and conducted general consumer surveys (Kumar, 2017). However, there is little research available in the literature on effects of adoption of cashless payments in Kenya. Along with popularity of electronic commerce and online purchasing, cashless payment systems have been developed and expected to the main payment means of ecommerce (Mallat, 2016). Despite the benefits associated with electronic money payments, a majority of Kenyans have generally been slow in adopting the use of cashless payments (Mbogo, 2016). The future of cashless payments seems promising and on the rise, if the challenges are addressed.

The Central Bank of Kenya (2017) report shows that cashless payments grew by 19 per cent to Sh2.31 trillion, nearly equaling the Sh2.37 trillion handled in 2014. This means Kenyans made an average of Sh192.7 billion of real-time mobile-based payments monthly, or Sh6.4 billion a day in the period to October 2015 compared to Sh5.4 billion daily in a similar period last year. Only 42 per cent of Kenyans over the age of 15 have bank accounts and only 30 per cent have debit cards. This low rate of financial inclusion typically creates substantial barriers for increasing cashless share of payments (Mahboub, 2018). According to Thomas and Angus (2013), cashless payments in Kenya achieved a double-digit growth which is attributed to the convenience of the platform and the increased utility of M-Pesa.

Upadhyay and Jahanyan (2016) note that key challenges beyond financial inclusion rates include low availability and affordability of financial services, infrastructure challenges and a large informal sector. In Kenya, several studies have been undertaken relating to effect of adoption of cashless payments. The studies sought to establish the impact of financial innovation on commercial banks in Kenya. Shukla (2017) carried out a study to establish the relationship between financial innovation and the growth of commercial banks in Kenya. The study was based on profitability to base the banks revenues, pretax profits, customer deposits, loan advances and number of innovations. The research found out that financial innovation greatly influences the financial performance of listed commercial banks in Kenya. .He also identified a research gap to the fact that past studies did not exhaust such aspects as efficiency, risk and performance but rather centered on productivity.

It is therefore evident that previous studies have not covered the effects of financial accessibility, financial innovations, cash handling practises and transaction costs on financial performance of 
supermarkets in Nairobi County. This study therefore intends to investigate how these factors impact the financial performance.

\section{General Objective of the Study}

The research aims to investigate effect of cashless payments on the financial performance of supermarkets in Nairobi County. The specific objectives were to examine the effect of financial accessibility, investigate the effect of financial innovations, examine the effect of cash handling practices and the effect of transaction costs on the financial performance of supermarkets in Nairobi County, Kenya

\section{Research Questions}

The following research questions guided the study:

i. How does financial accessibility influence financial performance of supermarkets in Nairobi County?

ii. To what extent do financial innovations influence financial performance of supermarkets in Nairobi County?

iii. How do cash handling practices influence financial performance of supermarkets in Nairobi County?

iv. To what extent do transaction costs influence the financial performance of supermarkets in Nairobi County?

\section{Scope of the Study}

The study covered 147 supermarkets registered and licensed to operate in Kenya. The supermarkets that formed the units of analysis of the study are those that were in operation by close of business of 31 December 2017 for the past 3 years. The research intent based its study in Nairobi County as most local, foreign owned and online supermarkets are based in the County, it is also a financial capital of the country and represents all the classes of buyers in the market. The study looked at the emerging trends and various forms of payments that have been introduced over the period. This study will aim to study the influence of financial accessibility, financial innovations, cash handling practises and transaction costs and their impact on financial performance on supermarkets in Nairobi County. The financial performance measures used were income, operating costs and return on assets. Data collection was conducted in the year 2018. This study utilises both primary and secondary data.

\section{Literature Review}

\section{Theoretical Review}

\section{Financial Inclusion Theory}

The Financial Inclusion theory as postulated by Porter (2014) states that financial inclusion refers to the process of ensuring access to appropriate financial products and services needed by all sections of the society in general and vulnerable groups such as weaker sections and low-income groups in particular, at an affordable cost, in a fair and transparent manner, by mainstream institutional players. This theory supports how financial accessibility influences financial performance. Financial inclusion theory states that an inclusive financial sector is one that provides access to credit for all 
bankable people and firms, to insurance for all insurable people and firms, to savings and payment services for everyone (Osei-Assibey, 2015).

Singh and Roy (2015) critical assessment of the concept of financial inclusion envisages the importance of having an inclusive financial system. Most of the definitional aspects of financial exclusions hovers around lack of access whether voluntarily or involuntarily by certain sections of the consumers to appropriate low cost, safe and fair financial products that might act as catalyst to their economic growth by providing financial stability to the section of population who are excluded from the formal financial system. Exclusion could occur for many reasons like because of inconvenient and un-affordable product, ignorance of the customer, lack of financial literacy, high transaction cost and low outreach of banks (Marinč, 2013). To bring about financial inclusion these hurdles have to be removed by effective policy initiative after a through comprehensive measurement of financial inclusion from both supply and demand side (Chakraborty, 2012).

\section{Developer-Based (Diffusion) Theory}

The Developer-based (diffusion) theory was postulated by Rogers (1995) and states that many factors interact to influence the diffusion of an innovation. The four major factors that influence the diffusion process are the innovation itself, how information about the innovation is communicated, time, and the nature of the social system into which the innovation is being introduced (Rogers, 1995). This theory supports how financial innovations influence financial performance.

The essential constraint of instructional development theory, and the exploration advancement structure worldview whereupon it is based, is their inalienable deterministic inclination. There is a general agreement in the dispersion and selection writing that mechanical prevalence alone isn't sufficient over assurance the appropriation of an advancement. Actually, some would contend whether mechanical prevalence is even a vital condition, at any rate toward the start of the selection procedure (MacKenzie, 1996). In the event that mechanical prevalence isn't adequate over increment reception, where does that abandon us? A few instructional technologists recommend that a definitive response to this imperative inquiry can be found in a more instrumentalist way to deal with dispersion.

\section{Technology Acceptance Model (TAM) Theory.}

The Technology Acceptance Model theory was postulated by Davis (1989) and states that Perceived Usefulness and Perceived Ease of Use are the main drivers of technology and determine an individual's intention to adopt a technology. This theory supports how cash handling practices influence financial performance. According to Bátiz-Lazo (2018), the intention to use serves as mediator of the actual adoption of technology. According to TAM, the decision to adopt a technology follows the four stages, explained as follows according to Bátiz-Lazo (2018). Stage one is where the external variables such as individual user beliefs or differences with Information Technology. Their evaluation is reflected in Perceived Usefulness (PU) and Perceived Ease of Use (PeU). Whereas perceived usefulness is a user perception that using the new system would increase his/her 
performance in the organization and perceived ease of use is the extent to which using the new system would require minimal effort on a user's behalf (Tilakaratna, 2016).

Stage two is attitude which is a consequence of the user's beliefs of using a technology drives the user's attitude towards accepting/rejecting the technology. Stage three is intention where the attitude predicts the desirability of the user using the system and the extent of them using it. Stage four is actual use which is the user's intention to determine how well they would actually use the system. The adoption of technology depends on personal behaviour and external environment. People perceive that by using technology, they will obtain more benefits without doing much physical and mental effort (Tilakaratna, 2016).

Gefen, Karahanna and Straub (2003) studied a separate and distinct interaction of both the actual evendor and with its IT Web site interface is at the heart of online shopping. Previous research has established, accordingly, that online purchase intentions are the product of both consumer assessments of the IT itself-specifically its perceived usefulness and ease-of-use (TAM)-and trust in the e-vendor (Nithin \& Baiju, 2018). The research showed that consumer trust is as important to online commerce as the widely accepted TAM use-antecedents, perceived usefulness and perceived ease of use. Thus these variable sets explain a considerable proportion of variance in intended behavior. The study also provided evidence that online trust is built through the belief that the vendor has nothing to gain by cheating, the belief that there are safety mechanisms built into the Web site, and lastly by having a typical interface that is easy to use.

\section{Transactions Cost Economics Theory}

The Transaction cost economics theory was postulated by Williamson (1981) and states that transaction costs arise every time a product or service is being transferred from one stage to another, where new sets of technological capabilities are needed to make the product or service.

It further states that the transaction costs related to the exchange of resources with the external environment could be reflected by environmental uncertainty, opportunism, risks, bounded rationality, core company assets. These factors above will all potentially increase the external transaction costs, where it may become rather expensive for a company to control these factors. Therefore, it may very well be more economical to maintain the activity in-house, so that the company will not use resources on e.g. contracts with suppliers, meetings and supervision. Therefore, if companies see the environmental uncertainty as high, they might choose to not outsource or exchange resources with the environment. This theory supports the influence transaction costs on the financial performance.

Firms intending to adopt cashless payments must choose between two options that is to purchase a cashless payment system from the vendors or to build its own cashless payment system to reduce its operational costs. The first option is considered as "a market based" mechanism in which organizations try to find the best product in the market to suit their needs. This option shows that the transaction costs include the costs of finding information on cost and acceptability of best payment system for the firm. The second option can be called "vertical integration" in that all costs 
of building the payment platform press on the organization through hierarchical means (Williamson, 1993).

Notwithstanding the tremendous impact of Transaction costs theory, its assumption has been subjected to multiple criticisms. For example, the assumption of resourcefulness has been criticized for ignoring that human actions influence organizational decisions and that not all decisions will be the same where the resources are the same. (Granovetter, 1985). Williamson responded by re-stating that in his model, opportunism or bounded rationality may differ from person to person much as personality or intelligence do, but when transaction costs change they do so because of changes in the environment, not in the person (Williamson, 1993a,b).

\section{Conceptual framework}

Figure 1: Conceptual framework

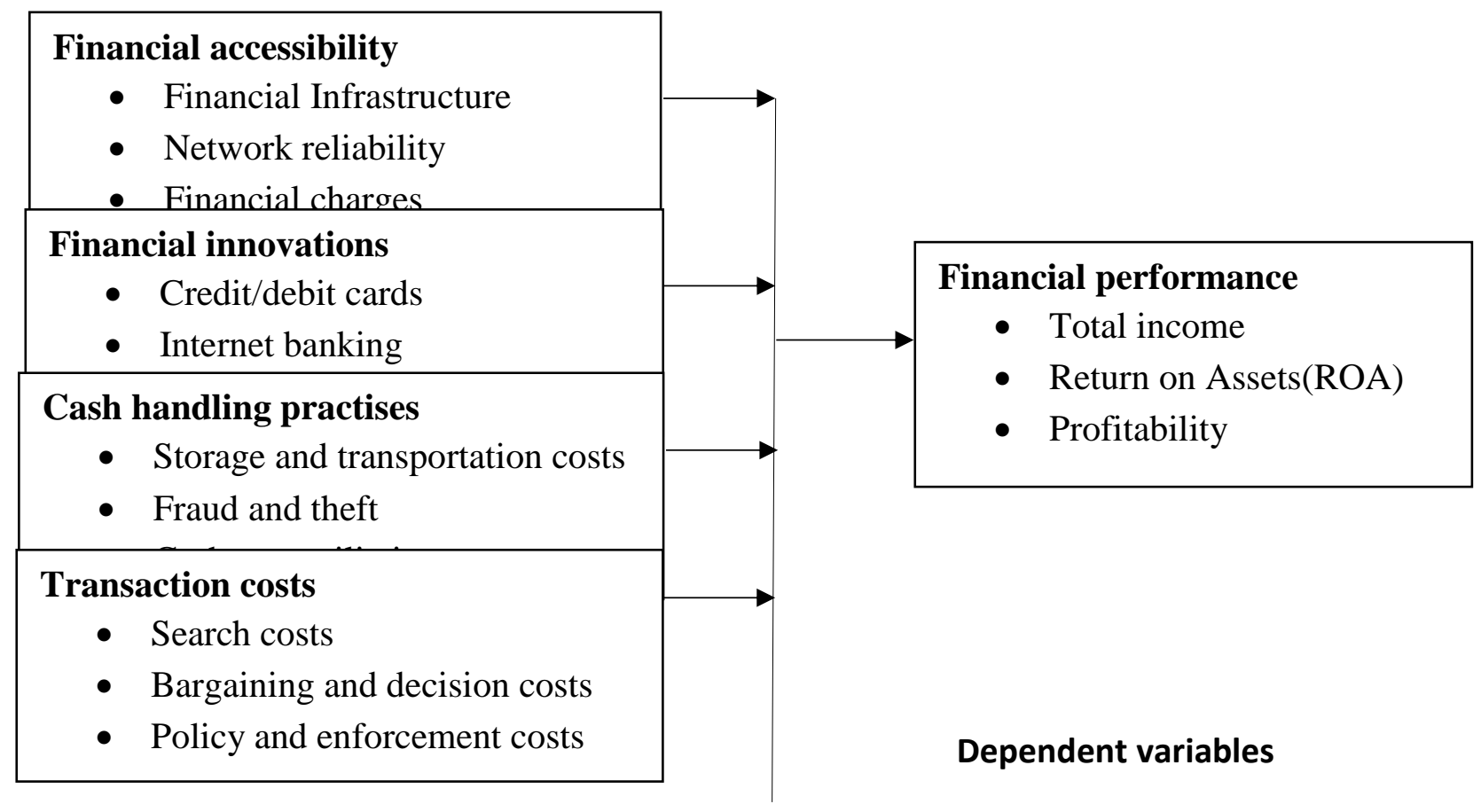

\section{Financial Accessibility}

Financial Accessibility is defined as the availability of a supply of quality financial services at fair costs, where quality and fair costs have to be defined relative to some objective standard, with costs reflecting all pecuniary and non-pecuniary costs (Hastomo \& Aras, 2018). Theoreticians have argued that lack of access to finance generates persistent income inequality or poverty traps and limits financial performance of Supermarkets in Nairobi County Without inclusive financial systems, supermarkets need to rely on sales initiatives to take advantage of growth opportunities. Financial market imperfections, such as information asymmetries and transactions costs, are likely to be 
especially binding on the retail customers thus limiting their purchasing power leading to slow growth (Tee \& Ong, 2016). The inability of the formal financial sector to meet the financial needs of the banked population leads to reliance on the informal and semiformal methods of payments

In computer systems and networking, availability is a general term that is used to describe the amount of time over a one-year period that the system resources are available in the wake of component failures in the system. To ensure system availability, information should be should be available and accessible to those who need it. Laudon (2017) states that continued availability of the information system and all its assets to legitimate users at an acceptable level of service or quality of service affects its adoption and any event that degrades performance or quality of a system affects availability. Burns (2015) point out that loss of network availability may have a serious impact on the business or service and thus influence adoption of a technology.

\section{Financial Innovations}

Financial innovations can be grouped as new products (e.g subprime mortgages) or services (e.g., Internet banking) which are introduced to enhance market demand or to improve the efficiency of the institution. In addition, product innovations relate to the introduction of new credit, deposit, insurance, leasing, hire purchase and other financial products. Another group is new production processes (e.g., new clearing house) which have led to increased efficiency and market expansion, this includes office automation and use of computers while another group is new organizational forms (e.g., Internet only banks) which relates to changes in business structures or setting up a completely new service structure this includes Internet only banks.

Some of the factors that have been fronted as determinants of improved access include financial innovations such as ability of supermarkets to accept credit card payments and mobile money payments. Introduction of digital banking and cashless payments in mainstream financial institutions, technological advances and improved standards of living and less regulations of the banking sector have increased domestic consumption. However, it has also been observed that these innovations in the formal financial sectors do not necessarily decrease the reliance on the informal financial sectors of an economy (Khraisha \& Arthur, 2018). Integration of financial institutions with supermarkets to allow for purchase of goods on credit is a milestone towards ensuring financial inclusion.

\section{Cash handling practices}

Porter (2014) find that the risk of fraud/theft related to bill paying activities has a significant negative impact on card usage. In the context of online payment systems, a potential exists for intercepting credit/debit card information such as transacting business over an unsecured wireless network. Consumers may hesitate to use online payment systems because of privacy concerns. The more customers are concerned about security of a cashless payment system, the greater the risk and less trustworthiness they would perceive in using the cashless payments and the less their intention to adopt the system. 
Consumers may hesitate to use online payment systems because of security concerns. Invasion of privacy in e-commerce includes the unauthorised collection, disclosure or other use of personal information such as selling it to another e-vendor (Wang \& Lee, 2010) and safeguarding privacy would typically cause an added cost to the consumers. This is like Pavlou's (2003) environmental uncertainty involving perceived risk associated with exposure of personal information.

\section{Transaction costs}

Search costs are one facet of transaction costs or switching costs. Rational consumers will continue to search for a better product or service until the marginal cost of searching exceeds the marginal benefit. According to Aranyossy (2018) costs of searching are divided into external and internal costs. External costs include the monetary costs of acquiring the information, and the opportunity cost of the time taken up in searching. Internal costs include the mental effort given over to undertaking the search, sorting the incoming information, and integrating it with what the consumer already knows. Internal costs are determined by the consumer's ability to undertake the search, and this in turn depends on intelligence, prior knowledge, education and training. These internal costs are the background to the study of bounded rationality.

Bargaining and decision costs are costs are the costs required to come to an acceptable agreement with the other party to the transaction and includes contract costs. These costs depend on the bargaining power of the firm. According to Bertonèche and Knight (2013) large firms tend to have a higher bargaining power compared to small and medium sized supermarkets companies. This in turn leads to lower transaction costs for large supermarkets and therefore lower payment charges compared to the small supermarkets

Policing and enforcement costs are the costs of making sure the other party sticks to the terms of the contract, and taking appropriate action if this turns out not to be the case. Enforcement costs are fixed in the sense that they do not depend on the number of individuals who commit harmful acts while other costs are variable they rise with the number of such individuals. Bertonèche and Knight (20013) report that optimal fine rises to reflect variable enforcement costs and that the optimal fine is not directly affected by fixed enforcement costs and that the optimal probability depends on both types of enforcement costs.

\section{Empirical Literature Review}

\section{Financial Accessibility}

Gerpott (2018) in his study found that attitude towards financial services and its usage is significantly affected by prior technological experience, personal banking experience and reference group influence. The study is further corroborated by Han, Keys and Li (2015), by noting that web benefits (information quality, information accessibility, information sharing, and transaction benefit) and web barriers (organisation barrier, trust, and legal support) are key factors influencing cashless payment adoption by customers. Viewing financial services from the customer's point of view is an important step on the way towards a lasting solution (Saarijärvi, Mitronen \& Yrjölä, 2014). He adds that the ease of use is the most important aspect and adds that unfulfilled identified needs within clear consumer segments must form the basis upon which financial services must be build. 


\section{Financial Innovations}

Munjeyi et el (2017) researched with the aim of finding out the factors that were considered in choosing and using the payment instruments. He used unique and new set of micro data that had both transaction information and survey data on the payment behavior of the Zimbambwean persons, the results showed that usage of cash was compatible with the rational decision making. Juariah (2015) highlighted various benefits of financial innovations in payments. The first advantage is having a faster transaction. Making queues at the point of sales terminal and vending machines has greatly been reduced as there can be direct transactions even at the comfort of one's home, therefore, increasing the speed of services and reducing the staff level at off peak times. The cashless payment have lend to increase of sales as it can be operated 24 hours by use of the card which operates 24 hours and 7 days in a week, thus increasing the time available for commercial activities and this add to increased sales and having better relationships. Also it has made cash collection simple as no much time is spent calculating and sorting cash cost money.

\section{Cash Handling Practices}

According to Hastomo and Aras (2018) various studies on consumer perceptions of system security have been conducted in the context of online banking but the perceived risk variable has only been modelled as a single construct, which fails to reflect the characteristics of the perceived risk. Bilgihan, (2016) conducted a study generation Y Internet (online) banking adoption. In this study, risk was divided into five facets; performance risk, social risk, financial risk, time risk and security risk. Given the similarities between cashless payments and Internet banking, these five risk facets will also be used for this study. According to Chalomba and Gujral (2016) these five risks were described for cashless payments as follows. Performance risk was referred to losses incurred by deficiencies or malfunctions of mobile banking servers. According to Bilgihan, (2016) a malfunction of a payment platform server would reduce customer willingness to use Internet banking services, and the same applies for cashless payments, this will in turn influence the adoption of cashless payments.

\section{Transaction Costs}

Rogoff (2015) found that consumers will not adopt paperless payment unless it reduces their costs and does not require them to change their behaviour when using it. According to Mahran and Enaba (2018) the main determinants of transaction costs are frequency, specificity, uncertainty, limited rationality, and opportunistic behaviour. These factors tend to be the main drivers of cashless payments. The result of this study was like that of Hassan, Renzis, and Schmiedel (2015) who did explore the fundamental relationship between the electronic retail payment and the growth of the economy. Using data from 27 European market over the period 1995-2009 the results were migration to the electronic retail payment was related to the overall consumption economic growth and trade. A study conducted by Ighobor and United Nations (2017) on Africa's quest for a cashless depicted that the perceived cost had little significance as compared to other variables like perceived risk, compatibility and perceived usefulness. Further, qualitative investigation on the same study was conducted. This study showed that the perceived cost normally is the major concern when technology is introduced. Moreso, when sudden needs or emergency happens, the utility benefits outweigh the cost issues. Hasan, Renzis and Schmiedel, (2015) conducted the study on respondents 
with the average level of income of US\$650 every month which was equivalent to Ksh 55,250 . This level of income was viewed as appropriate showing that the users could easily afford to pay by use of the cashless platforms in Kenya.

\section{Critique to the Existing Literature}

From reviewed relevant literature, it has come out strongly from several writers like; Cocosila \& Trabelsi (2016), Hastomo and Aras (2018), Laudon (2017), Yao (2014), Khraisha and Arthur (2018), Wang and Lee (2010), Cocosila and Trabelsi (2016), Bátiz-Lazo (2018) and Aranyossy (2018) that cashless payments have a positive impact on financial performance. They have agreed that cashless payments impact financial performance. However other scholars like; Gerpott (2018), Koech (2016), Chalomba and Gujral (2016) and Bilgihan, (2016) found out that cashless payments had a negative impact on supermarkets and have promoted the rise of shell (Virtual) supermarkets. These mixed results and alternative views from different countries and writers are mainly because of lack of comprehensive analysis of cashless payments and financial performance. This study intends to take a departure from past studies and incorporate several variables and their effect on financial performance. There is also concentration of innovation-performance studied on profitability and mostly in developed and emerging economies leaving a paucity of innovation performance literature for Africa and Kenya specifically. Most studies on effects of cashless payments are common in many developed countries such as Europe, The United States of America and Canada. This literature gap is addressed by this comprehensive study.

\section{Research Methodology \\ Research Design}

The study adopted descriptive research design to generate answers to the research questions. This design is selected because it allows the researcher to gather both numerical and descriptive data to assess the relationship between the independent and the dependent variables.

\section{Target population}

The population entailed all retail supermarkets in Nairobi County. The total number of retail stores are 147 supermarkets within $40 \mathrm{Km}$ radius (Kenya Retail Sector Report 2018). It is from this list that the researcher sampled the ones to be considered for the study.

\section{Sampling frame}

In Jason \& In Glenwick, 2016 formula below was used in obtaining the sample size.

$\mathrm{N}=\left(N /\left(1+N(e)^{2}\right)\right.$

Where; $\mathrm{N}=$ Sample size and

$\mathrm{e}=$ Level of precision.

The study assumed a precision level of 10\%; the supermarkets with more than one branch are 7 while those with one branch only are 140. Using the formula above, the size for each stratum is; $\mathrm{N} 1=7 /(1+7(0.1) 2)=6.5$ rounded up to 7 .

$\mathrm{N} 2=140 /(1+140(0.1) 2)=58.3$ rounded up to 59 . 
INTERNATIONAL JOURNAL OF ACADEMIC RESEARCH IN BUSINESS AND SOCIAL SCIENCES

Vol. 9, No. 3, March, 2019, E-ISSN: 222 2-6990 ¿ 2019 HRMARS

Where N1 represents the supermarkets with more than one branch and N2 represents supermarkets with one branch. The total sample is $(59+7)$ equal to 66 supermarket branches.

\section{Sample and sampling technique}

Stratified sampling technique is applied because of the variations in the target population. The supermarkets were divided into two stratums, that is, those with one outlet and those with more than one outlet. Proportional stratified sampling is used to select samples from each of the stratum representing the population.

\section{Data Collection procedure}

Primary data is collected using questionnaires. In terms of secondary data, the study used publicly available statistical reports and publications from Ministry of Industry, Trade and Cooperatives and the Kenya Retail Sector Report 2018.

\section{Data analysis and Presentation Data analysis}

Data was analysed using SPSS. The study adopted multiple regression analysis method and the following analytical model is used.

$Y=a+\beta_{1} X_{1+} \beta_{2} X_{2}+\beta_{3} X_{3}+\beta_{4} X_{4}+\varepsilon$

Where;

$B$ is co-efficient of variables $X_{1}, X_{2}, X_{3}, X_{4}$

$Y$ is the financial performance of supermarkets in Nairobi County

$a$ is constant term of $y$ when $x=0$

$\mathrm{X}_{1}$ represents financial accessibility

$X_{2}$ represents financial innovations

$\mathrm{X}_{3}$ represents cash handling practises

$\mathrm{X}_{4}$ represents transaction cost

$\varepsilon=$ Error margin

To test the relationship between the variables the study adopted a descriptive and inferential analysis. The inferential statistical procedures used in this study were correlation coefficient $(r)$ and Pearson correlation coefficient. The tests of significance used were regression analysis and expected to yield the coefficient of determination (R2), analysis of variance along with the relevant $t-$ tests, $f$ -tests, $z$ - tests and $p$ - values. The choices of these techniques were guided by the variables, sample size and the research design. The inferential statistical techniques were be done at $95 \%$ confidence level $(\alpha=0.05)$. The data is analysed using the Statistical Package Social Sciences Software (SPSS version 22). Quantitative data is used to present results in form of graphs and tables

\section{Data Presentation}

Data is presented in both tables and figures. 
INTERNATIONAL JOURNAL OF ACADEMIC RESEARCH IN BUSINESS AND SOCIAL SCIENCES

Vol. 9, No. 3, March, 2019, E-ISSN: 222 2-6990 ¿ 2019 HRMARS

Data Analysis, Findings and Discussion

Response Rate

The study had a sample size of 66 respondents. Out of 66 respondents, 48 responses were obtained giving a response rate of $73 \%$. According to Kothari (2004) any response of $50 \%$ and above is adequate for analysis thus $73 \%$ is excellent. The results of response rate are presented in Table 1.

Table 1: Response Rate

\begin{tabular}{lcc}
\hline Target no of respondents & No. of questionnaires returned & Response rate \\
\hline 66 & 48 & $73 \%$ \\
\hline
\end{tabular}

\section{Background Information}

The study collected information pertaining the general information regarding the organization and cashless payments in supermarkets in Nairobi County.

\section{Benefits of cashless payments}

The respondents were asked to indicate what the benefits of cashless payment according to them are. From the findings, $42 \%$ of the respondents indicated convenience as the major benefit of cashless payments, followed by lower transaction cost, safety and lastly fast.

\section{Eliminate the need for cash}

The respondents were asked to indicate if the availability of cashless payments would eliminate the need for cash. According to the findings, $72 \%$ of the respondents are of the opinion that cashless payments would eventually eradicate the need to carry cash for shopping. $28 \%$ of the respondents believe that cashless payments would not eliminate the need for cashless payments due to the occasional failures in the cashless payments systems.

\section{New technology}

The respondents were requested to indicate their level of comfort with new technology relating to cashless payments. According to the findings, 30\% of the respondents stated they are not comfortable with new cashless payment technology whereas $37 \%$ of the respondents are comfortable with new technology. $35 \%$ of the respondents are not sure of how they will handle new cashless payment technology.

\section{Descriptive Findings and Discussions \\ Financial accessibility}

The study analysed the views of respondents in respect of financial accessibility on financial performance of Supermarkets in Nairobi County. 
INTERNATIONAL JOURNAL OF ACADEMIC RESEARCH IN BUSINESS AND SOCIAL SCIENCES

Vol. 9, No. 3, March, 2019, E-ISSN: 222 2-6990 @ 2019 HRMARS

Table 2: Descriptive Statistics for Financial Accessibility

\begin{tabular}{|c|c|c|c|c|c|}
\hline Financial accessibility & $\mathrm{N}$ & Min & Max & Mean & Std Dev \\
\hline $\begin{array}{l}\text { It is easy to obtain point of sale(POS) machine or } \\
\text { pay bill number }\end{array}$ & 48 & 1 & 5 & 3.73 & 0.86 \\
\hline $\begin{array}{l}\text { Most banks offer the POS or pay bill number } \\
\text { services }\end{array}$ & 48 & 1 & 4 & 3.12 & 1.02 \\
\hline $\begin{array}{l}\text { Network issues occasionally disrupt the payment } \\
\text { thus forcing customers to pay using other means. }\end{array}$ & 48 & 2 & 5 & 3.08 & 1.05 \\
\hline $\begin{array}{l}\text { The commissions deducted by financial } \\
\text { institutions as a result of processing the payments } \\
\text { are high compared to cash handling costs }\end{array}$ & 48 & 1 & 5 & 3.40 & 1.04 \\
\hline $\begin{array}{l}\text { There is a potential risk of default in payment by } \\
\text { the customer if they have insufficient funds }\end{array}$ & 48 & 1 & 5 & 3.33 & 1.17 \\
\hline $\begin{array}{l}\text { There are delays by the banks in processing the } \\
\text { payments thus causing delays in meeting daily } \\
\text { obligations }\end{array}$ & 48 & 1 & 5 & 3.25 & 0.96 \\
\hline
\end{tabular}

According to the findings, the respondents agreed that it is easier to obtain a point of sale machine or paybill number (mean $\approx 3.73$; std dev $=0.86$ ). They also agreed that network issues disrupt payments thus forcing customers to pay using alternative channels (mean $\approx 3.08$; std dev $=1.05$ ). They further agreed that it is easier to obtain point of sales machines or paybill numbers (mean $\approx 3.73$; std dev $=0.86$ ) and that most banks offer the POS or paybill number services (mean $\approx 3.12$; std dev $=$ 1.02). They also agree that there is a potential risk of default in payment by customers (mean $\approx 3.33$; std dev $=1.17$ ) and that there are delays by the banks in processing the payments resulting to cash flow constraints (mean $\approx 3.25$; std dev $=0.96$ ).

This study is in agreement with Keys \& Li (2015), who argued that web benefits (information quality, information accessibility, information sharing, and transaction benefit) and web barriers (organisation barrier, trust, and legal support) are key factors influencing financial accessibility and thus influence the customers decision to use the cashless payment system. Gerpott (2018) further states that convenience, efficient operation, security and privacy, reliability and responsiveness influence individual's ability to financial access

\section{Financial Innovation}

The study put into perspective the opinions of respondents regarding the influence of financial innovation on the financial performance of Supermarkets in Nairobi County. 
INTERNATIONAL JOURNAL OF ACADEMIC RESEARCH IN BUSINESS AND SOCIAL SCIENCES

Vol. 9, No. 3, March, 2019, E-ISSN: 222 2-6990 @ 2019 HRMARS

Table 3: Descriptive Statistics for Financial innovation

\begin{tabular}{|c|c|c|c|c|c|}
\hline Financial innovations & $\mathrm{N}$ & Min & Max & mean & Std dev \\
\hline $\begin{array}{l}\text { Sales have increased because of financial } \\
\text { innovations in payments }\end{array}$ & 48 & 1 & 5 & 3.35 & 1.32 \\
\hline $\begin{array}{l}\text { Financial innovations relating to payments } \\
\text { have reduced time taken to serve a customer }\end{array}$ & 48 & 1 & 5 & 3.83 & 1.15 \\
\hline $\begin{array}{l}\text { Customers now have many options for paying } \\
\text { thus improved customer retention }\end{array}$ & 48 & 1 & 5 & 3.35 & 1.19 \\
\hline $\begin{array}{l}\text { The infrastructure available supports cashless } \\
\text { payments by customers }\end{array}$ & 48 & 1 & 5 & 3.92 & 1.14 \\
\hline $\begin{array}{l}\text { The financial innovations in payments have } \\
\text { increased market share of the company }\end{array}$ & 48 & 1 & 5 & 3.95 & 1.28 \\
\hline $\begin{array}{l}\text { The financial innovations in payments have } \\
\text { reduced operational costs }\end{array}$ & 48 & 1 & 5 & 3.58 & 0.61 \\
\hline
\end{tabular}

According to the findings, the respondents agreed that sales have increased because of financial innovations in payments (mean $=3.35$; std dev $=1.32$ ). The respondents also agreed that the financial innovations have reduced the time taken to serve a customer (mean $=3.83$; std dev $=1.15$ ). The respondents also agreed that that financial innovations in payments have increased the market share of the company (mean $=3.35$; std dev $=1.19$ ) and that the infrastructure available supports cashless payments (mean $=3.92$; std dev $=1.14$ ). They also agreed that financial innovations in payments have increased the market share of the company (mean $\approx 3.95$; std dev $=1.28$ ) and financial innovations in payments have reduced operational costs (mean $\approx 3.58$; std dev $=0.61$ ).

The above findings concurred with the observations of an earlier study by Juariah (2015) that financial innovations in payments have reduced queue time, increasing the speed of services and reducing the staff level at off peak times and as a result led to increase of sales as it can be operated 24 hours by use of the card. The above findings further concurred with the observations of an earlier study by Munjeyi et el (2017) that showed that usage of cash was compatible with the rational decision making. It is the role of the consumers to decide upon the adoption of the payment cards and use the available means of payment in accordance to their transactions and personal characteristics, the relative cash costs and usage of card and preferences.

\section{Cash Handling Practises}

The study sought to establish the effect of cash handling risks and practices on financial performance of Supermarkets in Nairobi County. The respondents were asked to rate each risk in terms of impact on the financial performance. 
INTERNATIONAL JOURNAL OF ACADEMIC RESEARCH IN BUSINESS AND SOCIAL SCIENCES

Vol. 9, No. 3, March, 2019, E-ISSN: 222 2-6990 @ 2019 HRMARS

Table 4: Descriptive Statistics for cash handling practises

\begin{tabular}{|c|c|c|c|c|c|}
\hline Cash handling practises & $\mathrm{N}$ & Min & Max & Mean & Std dev \\
\hline $\begin{array}{l}\text { The company holds large amounts of cash at any } \\
\text { time }\end{array}$ & 48 & 2 & 4 & 2.79 & 0.77 \\
\hline $\begin{array}{l}\text { The company has a cash management (storage, } \\
\text { transportation and reconciliation) policy. }\end{array}$ & 48 & 2 & 4 & 2.77 & 0.78 \\
\hline $\begin{array}{l}\text { The company regularly reviews the contracts of } \\
\text { companies which transport cash for them. }\end{array}$ & 48 & 2 & 5 & 3.31 & 1.17 \\
\hline $\begin{array}{l}\text { The company has invested heavily in CCTV } \\
\text { security cameras and strong rooms to safeguard } \\
\text { from theft. }\end{array}$ & 48 & 1 & 5 & 3.93 & 1.19 \\
\hline $\begin{array}{l}\text { The company has hired and trained staff on } \\
\text { conducting cash reconciliation. }\end{array}$ & 48 & 1 & 5 & 4.00 & 0.82 \\
\hline $\begin{array}{l}\text { Company has suffered losses due to cash theft, } \\
\text { robbery and fraud }\end{array}$ & 48 & 1 & 4 & 2.77 & 0.78 \\
\hline
\end{tabular}

From the findings, the respondents do not agree that the company holds large amounts of cash at any time (mean $\approx 2.79$; std dev $=0.77$ ), they also do not agree that the company has a cash management policy (mean $\approx 2.77$; std dev $=0.78$ ). They further disagreed that the company has suffered losses due to cash theft and robbery (mean $\approx 2.77$; std dev $=0.78$ ). However, they agreed that the company regularly reviews contracts of cash transport companies (mean $\approx 3.31$; std dev = 1.17) and that the company has invested heavily on security to safeguard cash (mean $\approx 3.93$; std dev $=1.19)$. They further agreed that the company has hired and trained staff on cash reconciliations ( mean $\approx 4.00$; std dev $=0.82$ ).

The findings of the study agree with the the study by Gerpott (2018), who used the construct perceived credibility ', which is defined as the extent to which a person believes that using mobile banking will have no security or privacy threats. For this study, security/privacy risk is like a lack of credibility. Time/convenience risk referred to a loss of time and any inconvenience incurred due to delayed payments or difficult navigation. He further explored the relationship between economic growth and e- payment system as the means of reviewing the current transition to cashless economy in Nigeria. The results depicted a significant positive relationship between the e- payments system and the economic growth in terms of Gross Domestic Product per capita and trade per capita. This research yields similar results as shown by the positive relationship between cashless payments and financial performance.

\section{Transaction Costs}

The study sought to establish influence of Transaction costs on financial performance. The respondents were asked to indicate the effect of transactions costs on financial performance. 
INTERNATIONAL JOURNAL OF ACADEMIC RESEARCH IN BUSINESS AND SOCIAL SCIENCES

Vol. 9, No. 3, March, 2019, E-ISSN: 222 2-6990 @ 2019 HRMARS

Table 5: Descriptive Statistics for transaction costs

\begin{tabular}{lccccc}
\hline Transaction costs & $\mathrm{N}$ & Min & Max & Mean & Std Dev \\
\hline $\begin{array}{l}\text { Investment in cashless payments technology takes a } \\
\text { huge portion of the company's capital }\end{array}$ & 48 & 1 & 5 & 3.19 & 1.07 \\
$\begin{array}{l}\text { The company incurs high recurrent costs to maintain the } \\
\text { cashless payments }\end{array}$ & 48 & 1 & 5 & 2.79 & 0.98 \\
$\begin{array}{l}\text { The company continues to invest in cashless payments to } \\
\text { ensure ease of payments }\end{array}$ & 48 & 2 & 4 & 3.75 & 0.88 \\
$\begin{array}{l}\text { Investments done relating to cashless payments have } \\
\text { resulted to increased sales }\end{array}$ & 48 & 2 & 5 & 3.90 & 0.69 \\
$\begin{array}{l}\text { Investments done relating to cashless payments have } \\
\text { reduced operational costs }\end{array}$ & 48 & 2 & 4 & 3.33 & 0.78 \\
$\begin{array}{l}\text { The company has incurred additional costs to ensure } \\
\text { smooth running of cashless payments (installing }\end{array}$ & 48 & 2 & 4 & 2.79 & 0.54 \\
generator and internet costs)
\end{tabular}

Respondents admitted that investment in cashless payments forms a huge percentage of the company's capital (mean $=3.19$; std dev $=1.07$ ). The respondents agreed that the company continues to invest in cashless payments to ensure ease of payments (mean $=3.75$; std dev $=0.88$ ) and that investments in cashless payments have resulted to increased sales (mean = 3.90; std dev =0.69)and reduction in operation costs (mean $=3.33$; std dev $=0.78$ ). The respondents however did not agree that the company incurs high recurrent costs to maintain the cashless payments (mean $=2.79$; std dev $=0.98$ ) and that the company has incurred additional costs to ensure smooth running of the cashless payments system (mean $=2.79$; std dev $=0.54$ ).

The findings of the study are supported by Hassan, Renzis, and Schmiedel (2015) who did explore the fundamental relationship between the electronic retail payment and the growth of the economy. Using data from 27 European market over the period 1995-2009 the results were migration to the electronic retail payment was related to the overall consumption economic growth and trade (Marinč, 2013). A study conducted by Ighobor, \& United Nations. (2017) on Africa's quest for a cashless depicted that the perceived cost had little significance as compared to other variables like perceived risk, compatibility and perceived usefulness.

Further, qualitative investigation on the same study was conducted. This study showed that the perceived cost normally is the major concern when technology is introduced. More so, when sudden needs or emergency happens, the utility benefits outweigh the cost issues. 
INTERNATIONAL JOURNAL OF ACADEMIC RESEARCH IN BUSINESS AND SOCIAL SCIENCES

Vol. 9, No. 3, March, 2019, E-ISSN: 222 2-6990 @ 2019 HRMARS

Financial Performance

Table 6: Descriptive Statistics for financial performance

\begin{tabular}{|c|c|c|c|c|c|}
\hline Financial performance & $\mathrm{N}$ & Min & Max & Mean & Std Dev \\
\hline Low access to financial services has resulted to low sales & 48 & 1 & 5 & 3.85 & 1.05 \\
\hline $\begin{array}{l}\text { The cost of investments in financial innovations on } \\
\text { payments has resulted to increased sales. }\end{array}$ & 48 & 1 & 5 & 3.79 & 0.92 \\
\hline $\begin{array}{l}\text { Improved cash management skills have reduced financial } \\
\text { losses thus improving profitability }\end{array}$ & 48 & 2 & 5 & 2.88 & 0.76 \\
\hline $\begin{array}{l}\text { Lower transaction costs in payments will increase sales } \\
\text { and profitability }\end{array}$ & 48 & 2 & 5 & 3.25 & 0.93 \\
\hline $\begin{array}{l}\text { Introduction of different payment methods will allow } \\
\text { customers to select their preferred option and likely to } \\
\text { increase sales }\end{array}$ & 48 & 2 & 4 & 3.56 & 0.94 \\
\hline $\begin{array}{l}\text { Benefits associated with cashless payments outweigh the } \\
\text { costs of cashless payment systems }\end{array}$ & 48 & 1 & 4 & 3.58 & 1.25 \\
\hline
\end{tabular}

Respondents agree that low access to financial services results to low sales (mean $=3.85$; std dev = 1.05). In addition, the respondents cost of investments in financial innovations on payments ( $m e a n=$ 3.79; std dev $=0.92$ ) and lower transaction costs in payments (mean $=3.25$; std dev $=0.93$ ) has resulted to increased sales. It was also agreed different payment methods will allow customers to select their preferred option and that improved cash management skills have reduced financial losses ( mean $=2.88$; std dev $=0.76$ ) and likely improve the profitability. Finally, the respondents agreed that the benefits associated with cashless payments outweigh the costs of the cashless payments (mean $=3.58$; std dev = 1.25).

The study agreed with Jain (2017) who states that efficient, safe and convenient, payments methods offer a significant range of macro-economic benefits through increased consumer consumption. 
INTERNATIONAL JOURNAL OF ACADEMIC RESEARCH IN BUSINESS AND SOCIAL SCIENCES

Vol. 9, No. 3, March, 2019, E-ISSN: 222 2-6990 ¿ 2019 HRMARS

Table 7: Regression co-efficients ${ }^{a}$

\begin{tabular}{|c|c|c|c|c|c|c|}
\hline \multirow[b]{2}{*}{ Model } & & \multicolumn{2}{|c|}{$\begin{array}{l}\text { Unstandardized } \\
\text { Coefficients }\end{array}$} & \multirow{2}{*}{$\begin{array}{l}\text { Standardized } \\
\text { Coefficients } \\
\text { Beta }\end{array}$} & \multirow[b]{2}{*}{$\mathrm{T}$} & \multirow[b]{2}{*}{ Sig. } \\
\hline & & B & Std. Error & & & \\
\hline \multirow[t]{5}{*}{1} & (Constant) & 10.646 & 2.486 & & 4.282 & .000 \\
\hline & Financial accessibility & 160 & .273 & .082 & .588 & .560 \\
\hline & Financial innovations & 301 & 419 & 101 & .718 & . 477 \\
\hline & $\begin{array}{l}\text { cash handling } \\
\text { practises }\end{array}$ & -1.373 & 442 & -.417 & -3.109 & .003 \\
\hline & transaction costs & -1.296 & .486 & -.368 & -2.667 & .011 \\
\hline
\end{tabular}

a. Dependent Variable: Financial Performance

The interpretations of the findings indicated follow the following regression model.

$Y=\beta 0+\beta 1 X_{1}+\beta 2 X_{2}+\beta 3 X_{3}+\beta 4 X_{4}+\varepsilon$

Therefore,

$Y=10.646+0.16 X_{1}+0.301 X_{2}-1.373 X_{3}-1.296 X_{4}$

The findings indicated that in order for financial performance to be increased by 1-unit, financial accessibility ought to be increased by 0.78 and financial innovations increased by 0.30 , cash handling risks and transaction costs are supposed to be reduced by 1.37 units and 1.296 units respectively. This ought to have held 10.646 constant. The findings indicated that transaction cost was the most fundamental factor that ought to have been considered by supermarkets in adopting cashless payments. The findings also indicated that financial accessibility $(t=-2.902 ; p>0.05)$, financial innovations $(t=-1.36 ; p>0.05)$, cash handling practices $(t=-1.9 ; p>0.05)$ and transaction costs $(t=$ $-3.32 p>0.05$ ) have significant effect on financial performance. In general, the four factors had a significant effect on financial accessibility $(t=3.883 ; p>0.05)$.

\section{Summary, Conclusions and Recommendations Financial Accessibility and Financial Performance}

Regarding the effect of financial accessibility on financial performance, it emerged from the results that financial accessibility has a huge impact on financial performance. It also shows that financial infrastructure is limited in terms of promoting cashless payments however, obtaining the cashless payment tends to be easier. Therefore, for supermarkets in Nairobi County to improve their financial performance, they should ensure to have accessibility to the cashless payment infrastructure as it is likely to boost sales.

\section{Financial Innovations and Financial Performance}

The results show how the financial innovations influence financial performance. The results revealed that debit and credit cards have increased significantly in the last 5 years and is still on the rise. Mobile 
banking is the predominant cashless payment available and is widely used. Internet banking is mainly used on the online supermarkets which do not accept cash payments and is slowly increasing with the rising number of online shopping. Therefore, to ensure increased sales and wider customer base, supermarkets in Nairobi County must adopt at least one of the cashless payments options.

\section{Cash Handling Practises and Financial Performance}

Regarding the effect of cash handling practices on financial performance, the study revealed that firms incur high costs on staff tasked with cash management and cash reconciliation functions. The respondents further agreed that firms incur huge costs on security and cash management firms. The results indicated that with managed cash handling practices, cash management costs/risks will reduce thus increasing the financial performance of supermarkets.

\section{Transaction Costs and Financial Performance}

The findings on the effect of transaction costs on financial performance revealed that investments in cashless payment systems are significant and that the companies continuously invest to better their cashless systems. It also revealed that sales have increased for the past year as a result of adopting cashless payments. It is notable that the respondents indicated that there are low recurrent costs to ensure functionality of the cashless payments. This reduction in costs and increase in sales subsequently result to improved financial performance of companies.

\section{Financial Performance}

It was admitted that large enterprises are likely to benefit more from adoption of cashless payments than smaller companies. The respondents also concurred that management decisions, government regulations and the nature of goods and services would result to improved financial performance and are thus fundamental to companies.

\section{Conclusions}

From the findings, the study concluded that financial accessibility influence financial performance of supermarkets in Nairobi County. It is easy to obtain cashless payments systems be it a POS machine or paybill number. The researcher also concluded network issues disrupt the cashless payments forcing customers to make payments with other payment options that may be costly. The study indicated that sales have increased as a result of innovations in payments which is credit and debit card payments, mobile money payments and internet banking. It also indicated that these innovations in payments have reduced operational costs thus increasing the profits for the supermarkets. From the study, most supermarkets have invested so much in security to manage cases of fraud and theft. The supermarkets have also hired staff to carry out daily cash reconciliations to ensure that all cash sales have been properly accounted for.

The study showed that first time investments in cashless payments take a huge portion of the company's capital and that the supermarkets do not have recurrent expenditure to maintain the cashless payments. The study further showed that supermarkets continue to do more investments in cashless payments to ensure that all needs of the different customers are taken into consideration. 
The study concluded that financial performance is affected by financial accessibility, financial innovations, cash handling practices and transaction costs.

\section{Recommendations}

In the light of the foregoing findings, the study recommends that financial performance depends significantly on financial accessibility and therefore the need to improve on the available financial infrastructure to cater for all payment needs of different consumers. This will increase sales from consumers. Supermarkets should also invest in network services to reduce the downtime caused by the different cashless payment systems. Furthermore, supermarkets should ensure to bargain more financial institutions to reduce the financial accessibility charges for uptake of the cashless payments. This will ensure that many supermarkets adopt the many cashless payment platforms available in the market.

The study also recommended that supermarkets should try to adopt internet banking. Currently, the most widely used cashless payments are mobile banking followed by use of debit /credit cards. Through adoption of internet banking, customers will be able to pay for their goods without going to the supermarkets with the goods being delivered at the customer's premises. This will boost sakes exponentially. Therefore, supermarkets should design their systems to be able to encompass the internet banking.

\section{Suggestions for Further Studies}

The study suggests that a replication of the above study should be carried out in other counties to establish whether similar findings will be obtained. In addition, further research should be carried out on factors influencing the adoption of cashless payments in Kenya. A study should also be carried out to determine effects of cashless payments on the transportation industry in Kenya.

\section{References}

Agwu, E. (2012). A Qualitative Study of the Problems and Prospects of Online Banking in Developing Economies-Case of Nigeria. Available at SSRN 3112130.

Akhisar, I., Tunay, K. B., \& Tunay, N. (2015). The effects of innovations on bank performance: The case of electronic banking services. Procedia-Social and Behavioral Sciences, 195, 369-375.

Aranyossy, M. (2018). Citizen adoption of e-government services - Evidence from Hungary. Digital Transformation - Meeting the challenges. doi:10.18690/978-961-286-170-4.3

Balaji, K. C., \& Balaji, K. (2017). A study on demonetization and its impact on cashless transactions. International Journal of Advanced Scientific Research \& Development, 4(3), 5864.

Bátiz-Lazo, B. (2018). Epilogue: The Cashless Economy and the ATM. Oxford Scholarship Online. doi:10.1093/oso/9780198782810.003.0010

Bertonèche, M., \& Knight, R. (2003). Financial performance. Oxford: Butterworth-Heinemann.

Bilgihan, A. (2016). Gen Y customer loyalty in online shopping: An integrated model of trust, user experience and branding. Computers in Human Behavior, 61, 103-113. 
INTERNATIONAL JOURNAL OF ACADEMIC RESEARCH IN BUSINESS AND SOCIAL SCIENCES

Vol. 9, No. 3, March, 2019, E-ISSN: 222 2-6990 @ 2019 HRMARS

Central Bank of Kenya. (2017). Publications. Nairobi: Government Press. https://www.centralbank.go.ke/publications

Chalomba, N., \& Gujral, M. (2016, July). Consumer Perceptions and Adoption of Mobile Payments in Johannesburg, South Africa: A Case of University Students. In 2016 Global Marketing Conference at Hong Kong (pp. 1310-1327).

Cocosila, M., \& Trabelsi, H. (2016). An integrated value-risk investigation of contactless mobile payments adoption. Electronic Commerce Research and Applications, 20, 159-170.

Singh, R. \& Roy, S. (2015). Asian Journal of Research in Business Economics and Management, Vol. 5, No. 1, pp. $12-18$

Gerpott, T. (2018). Experienced speeds of fixed Internet connections as drivers of customer bonds with their provider-An empirical study of consumers in Germany. Management Science Letters, 8(12), 1239-1258.

Han, S., Keys, B., \& Li, G. (2015). Information, Contract Design, and Unsecured Credit Supply: Evidence from Credit Card Mailings. Finance and Economics Discussion Series,2015(103), 154. doi:10.17016/feds.2015.103

Hasan, I., De Renzis, T., \&Schmiedel, H. (2015). Retail Payments and Economic Growth. SSRN Electronic Journal. doi:10.2139/ssrn.2100651

Hastomo, A. D., \& Aras, M. (2018). Influence of Cashless Society Socialization toward Trust Transaction Culture in Jakarta, Indonesia. Humaniora, 9(1), 1-13.

Hennart, J. F. (1993). Explaining the swollen middle: Why most transactions are a mix of "market" and "hierarchy". Organization science, 4(4), 529-547.

Ighobor, K. (2017). Africa's quest for a cashless economy gains momentum. Africa Renewal, 31(1), 16-17.

Jain, P. (2017). Cashless system of colleges in India. International journal of social sciences and humanities, 1(3), 1-7.

Jason, L., \& Glenwick, D. (Eds.). (2016). Handbook of methodological approaches to communitybased research: Qualitative, quantitative, and mixed methods. Oxford university press.

Juariah, R. (2015, May). Innovation Green Banking in Banking Service (Electronic Banking) to Improve Quality. In International Conference on Economics and Banking (iceb-15). Atlantis Press.

Kosse, A., Chen, H., Felt, M. H., Jiongo, V. D., Nield, K., \& Welte, A. (2017). The costs of point-of-sale payments in canada (No. 2017-4). Bank of Canada Staff Discussion Paper.

Kumar, L. (2016). Can Mobile Money Replace Cash in India?. In The Book of Payments (pp. 297-310). Palgrave Macmillan, London.

Laudon, K. C., \& Laudon, J. P. (2015). Management Information Systems: Managing the Digital Firm Plus MyMISLab with Pearson eText--Access Card Package. Prentice Hall Press.

MacKenzie, D. A. (1996). Knowing machines: Essays on technical change (inside technology). MIT Press.

Mahboub, R. M. (2018). The Impact of Information and Communication Technology Investments on the Performance of Lebanese Banks. European Research Studies Journal, 21(4), 435-458. 
INTERNATIONAL JOURNAL OF ACADEMIC RESEARCH IN BUSINESS AND SOCIAL SCIENCES

Vol. 9, No. 3, March, 2019, E-ISSN: 222 2-6990 @ 2019 HRMARS

Mahran, A. F., \& Enaba, H. M. L. (2011). Exploring determinants influencing the intention to use mobile payment service. International Journal of Customer Relationship Marketing and Management (IJCRMM), 2(4), 17-37.

Marinč, M. (2013). Banks and information technology: marketability vs. relationships. Electronic Commerce Research, 13(1), 71-101.

MasterCard. (2014). Cashless Journey: Tracking the Global Shift to Cashless Societies | Global Hub. Retrieved from https://newsroom.mastercard.com/digital-press-kits/cashless-journeytracking-the-global-shift-to-cashless-societies/

Mugambi, A., Njunge, C., \& Yang, S. C. (2014). Mobile-money benefits and usage: the case of MPESA. IT Professional, 16(3), 16-21.

Munjeyi, Edmore, Chiwira, Oscar, Maponga, Stephen, Samson. (2017). The Cashless Economy in Zimbabwe: The Golden Time to Tax the Informal Sector. The International Institute for Science, Technology and Education (IISTE.

Nithin, M., Jijin, P., \& Baiju, P. (2018). Has Demonetisation Pushed Digitalisation in India? Some Counter Evidences. Journal of Business Thought, 9, 58-69.

Osei-Assibey, E. (2015). Mobile Money and Financial Inclusion. Financial Inclusion for Poverty Alleviation, 118-135. doi:10.9774/gleaf.9781315103457_9

Porter, T. (Ed.). (2014). Transnational financial regulation after the crisis. Routledge.

Rafique, M., Rizwan, M., Batool, A., \& Aslam, F. (2014). Extending TAM, in terms of Trust and Attitude towards the online shopping intention. Journal of Public Administration and Governance, 4(3), 90-108.

Rogers, E. M. (1995). Diffusion of Innovations (4th Eds.) ACM The Free Press (Sept. 2001). New York, 15-23.

Rogoff, K. (2015). Costs and benefits to phasing out paper currency. NBER Macroeconomics Annual, 29(1), 445-456.

Roy, A. (2018). Business impacts of electronic banking technologies. International Journal of Electronic Banking,1(2), 113. doi:10.1504/ijebank.2018.10016639

Saarijärvi, H., Mitronen, L., \& Yrjölä, M. (2014). From selling to supporting-Leveraging mobile services in the context of food retailing. Journal of Retailing and Consumer Services, 21(1), 26-36.

Shukla, U. N. (2017). An empirical study on future of mobile-wallets in India: A gateway for cashless payments. Arthshastra: Indian Journal of Economics \& Research, 6(6), 51-62.

Son, I., \& Kim, S. (2018). Mobile Payment Service and the Firm Value: Focusing on both Up-and Down-Stream Alliance. Sustainability, 10(7), 2583.

Tee, H. H., \& Ong, H. B. (2016). Cashless payment and economic growth. Financial Innovation, 2(1), 4.

Thomas, H., Jain, A., \& Angus, M. (2013). Measuring progress toward a cashless society. MasterCard Advisors.

Tilakaratna, G. (2016). Financial Inclusion in Sri Lanka: Current Status and Issues. In Financial Inclusion in Asia (pp. 187-208). Palgrave Macmillan, London.

Upadhyay, P., \& Jahanyan, S. (2016). Analyzing user perspective on the factors affecting use intention of mobile based transfer payment. Internet Research, 26(1), 38-56. 
INTERNATIONAL JOURNAL OF ACADEMIC RESEARCH IN BUSINESS AND SOCIAL SCIENCES

Vol. 9, No. 3, March, 2019, E-ISSN: 222 2-6990 @ 2019 HRMARS

Williamson, O. E. (1993). Calculativeness, trust, and economic organization. The journal of law and economics, 36(1, Part 2), 453-486.

Williamson, O. E. (1993). Opportunism and its critics. Managerial and decision economics, 14(2), 97107.

WorldBank. (2016). Financial Access. Retrieved from

http://www.worldbank.org/en/publication/gfdr/gfdr-2016/background/financial-access 